\title{
MEMBANGUN PERAN GURU MELALUI SOSIOLOGI PENDIDIKAN
}

\section{Zulmawati}

Surel: zulma.wati@gmail.com

\begin{abstract}
In the world of education student development is influenced by parents, teachers, society. For this reason, teachers must understand and be equipped with educational sociology and skilled in operating it in educational activities. A teacher also has a very important role in creating an atmosphere in school life. By understanding the sociology of education the teacher is expected to know ways - how to control the educational process to develop individual personalities to be better. So that the fundamental problems of education can be overcome, therefore teachers as educators must try to analyze education from the sociology of education.
\end{abstract}

Keywords: Educational Sociology, Teacher, Teacher's Role

\begin{abstract}
ABSTRAK
Dalam dunia pendidikan perkembangan siswa dipengaruhi oleh orang tua,guru,masyarakat. Untuk itu, para guru harus paham dan dibekali dengan sosiologi pendidikan serta terampil mengoperasikannya dalam kegiatan pendidikan. Seorang guru juga mempunyai peranan yang sangat penting dalam menciptakan suasana dalam kehidupan sekolah. Dengan memahami sosiologi pendidikan guru diharapkan akan mengetahui cara - cara mengendalikan proses pendidikan untuk mengembangkan kepribadian individu agar lebih baik. Sehingga masalah - masalah pendidikan yang fundamental dapat teratasi, oleh karenanya guru sebagai tenaga pendidik harus berusaha menganalisis pendidikan dari sosiologi pendidikan.
\end{abstract}

Kata Kunci: Sosiologi Pendidikan, Guru, Peran Guru

\section{PENDAHULUAN}

Banyak orang menyadari bahwa pendidikan adalah wahana untuk membangun sumber daya manusia yang bermutu. Banyak orang pula telah memaklumi bahwa aktor utama dalam proses pendidikan dan pembelajaran adalah guru (pendidik). Unsur guru lah yang dapat memfasilitasi berkembangnya potensi siswa (peserta didik), mengubah prilaku, mendewasakan dan memandirikan sehingga siswa dapat tumbuh dan berkembang hingga menjadi dewasa . dalam hal ini guru memiliki posisi sebagai garda terdepan dan paling bertanggung jawab dalam membangun bangsa yang maju dan berkarakter. Tidak terlalu salah bila ada oknum peserta didik yang berprilaku menyimpang lalu masyarakat mempertanyakan siapa gurunya?

Guru menurut undang-undang no 14 tahun 2005 adalah pendidik profesional dengan tugas utama 
mendidik, mengajar, membimbing, mengarahkan, melatih, menilai dan mengevaluasi peserta didk pada pendidikan anak usia dini jalur pendidikan formal, pendidikan dasar dan pendidikan menengah

Peran guru juga sebagai komunikator, sahabat yang dapat memberikan nasihat-nasihat,motivator sebagai pemberi inspirasi dan dorongan, pembimbing dalam pengembangan sikap dan tingkah laku serta nilainilai, orang yang menguasai bahan yang diajarkan

Masalah pendidikan saat ini menjadi prioritas utama. Dalam pasal 31 UUD 45 ayat 1 dan 2 : "tiap-tiap warga Negara berhak mendapat pendidikan" dan " setiap warga negara wajib mengikuti pendidikan dasar dan pemerintah wajib,membiayainya“. Ini membuktikan adanya langkah pemerataan pendidikan bagi seluruh warga Negara Indonesia, sehingga tidak mustahil masalah pendidikan dalam operasionalnya akan semakin luas pula. Pemerataan kesempatan pendidikan juga telah menjangkau segala lapisan masyarakat di perkotaan dan pedesaan, termasuk anak pegawai dan pekerja, para pegawai sendiri, serta pekerja sampai pembantu rumah tangga yang masih ingin meningkatkan kariernya memanfaatkan kesempatan yang baik tersebut.

Jika penanganan masalah pendidikan hanya berlandas pada
teoriTorhrndike yakni pemberian ganjaran (reward) bagi yang patuh dan berhasil agar cenderung diulangulang (Ratna Willis Dahar: 1991), akan tetapi sebaliknya memberi hukuman (punishment) bagi yang tidak patuh atau melanggar larangan, tanpa memperhatikan faktor-faktor sosiologisnya, pendidikan kita akan kurang sukses. Terutama bagi peserta didk yang kondisi sosial ekonominya kurang menyenangkan serta sarana prasarana kurang memadai, maka tanpa memperhatikan peranan sosiologi pendidikan dengan seksama, pendidikan pun akan kurang berhasil pula. Apalagi untuk menangani kasus - kasus pendidikan yang berkaitan dengan masalah masalah sosial, seperti kenakalan anak didik, patus sekolah, pengangguran, kemiskinan, penyalahgunaan obat terlarang, sebagainya maka peranan sosiologi pendidikan terasa sekali faedahnya.

Untuk itu, para guru harus paham dan dibekali dengan sosiologi pendidikan serta terampil mengoperasikannya dalam kegiatan pendidikan. Seorang guru juga mempunyai peranan yang sangat penting dalam menciptakan suasana dalam kehidupan sekolah

\section{Sosiologi Pendidikan}

Beberapa defenisi sosiologi pendidikan menurut beberapa ahli: 1 .Menurut F.G. Robbins, sosiologi pendidikan adalah sosiologi khusus

\section{p-ISSN 2407-4934 \\ e-ISSN 2355-1747}


yang tugasnya menyelidiki struktur dan dinamika proses pendidikan. Struktur mengandung pengertian teori dan filsafat pendidikan, system kebudayaan, struktur kepribadian dan hubungan kesemuanya dengan tata sosial masyarakat. Sedangkan dinamika yakni proses sosial dan cultural, proses perkembangan kepribadian, dan hubungan kesemuanya dengan proses pendidikan.

2. Menurut H.P.Fairchild dalam bukunya "Dictionary of Sociology" dikatakan bahwa sosiologi pendidikan adalah sosiologi yang diterapkan untuk memecahkan masalah-masalah pendidikan yang fundamental. Jadi ia tergolong applied sociology.

3. Menurut Prof. DR S. Nasution, MA, sosiologi pendidikan adalah ilmu yang berusaha untuk

mengetahui cara - cara mengendalikan proses pendidikan untuk mengembangkan kepribadian individu agar lebih baik.

4. Menurut F.G. Robbins dan Brown, sosiologi pendidikan ialah ilmu yang membicarakan dan menjelaskan hubungan-hubungan sosial yang mempengaruhi individu untuk mendapatkan serta prinsip-prinsip untuk mengontrolnya.

5. Menurut E.G Payne, Sosiologi Pendidikan ialah studi yang komprehensif tentang segala aspek pendidikan dari segi ilmu sosiologi yang diterapkan.

6. Menurut Drs. Ary H. Gunawan, Sosiologi Pendidikan ialah ilmu pengetahuan yang berusaha memecahkan masalah-masalah pendidikan dengan analisa atau pendekatan sosiologis.

Dari beberapa definisi di atas, dapat disimpulkan bahwa sosiologi pendidikan adalah ilmu yang mempelajari seluruh aspek pendidikan, baik itu sturktur, dinamika, masalah-masalah pendidikan, ataupun aspek-aspek lainnya secara mendalam melalui analisis atau pendekatan sosiologis.

\section{HASIL DAN PEMBAHASAN}

\section{A. Sosok Guru Dalam Sosiologi Pendidikan}

Kita perlu memahami terlebih dahulu pengertian dari sosiologi pendidikan. Sosiologi pendidikan merupakan sebuah ilmu pengetahuan yang berusaha memecahkan masalahmasalah pendidikan dengan analisis atau pendekatan sosiologi. Menurut EG Paynye sosiologi pendidikan bertujuan utama memberikan pendidikan kepada guru-guru (termasuk para peneliti dan siapapun yang terkait dalam bidang pendidikan) latihan yang efektif dalam bidang sosiologi sehingga dapat memberikan sumbangan yang cepat dan tepat dalam dunia 
pendidikan

(https://fisipsosiologi.wordpress.com

). Francis Broun mengemukakan bahwa sosiologi pendidikan memperhatikan pengaruh keseluruhan lingkungan budaya sebagai tempat cara individu memperoleh dan mengorganisasi pengalamannya. Menurut S Nasution Sosiologi pendidikan adalah ilmu yang berusaha untuk mengetahui cara-cara mengendalikan proses pendidikan untuk mengembangkan kepribadian individu agar lebih baik. Sehingga masalah-masalah pendidikan yang fundamental dapat teratasi dengan pendekatan sosiologi (Gunawan Ary : 2000)

Kenyataan bahwa masyarakat mengalami perubahan sangat cepat, progresif dan kerap kali menunjukkan gejala disintegrative atau berkurangnya kesetiaan terhadap nilai-nilai umum. Perubahan sosial yang sangat cepat menimbulkan "cultural lag" (ketinggalan kebudayaan akibat hambatanhambatan). Dan ini merupakan sumber masalah sosial dalam masyarakat. Masalah-masalah sosial juga dialami dunia pendidikan, sehingga lembaga-lembaga pendidikan tidak mampu mengatasinya. Maka para ahli sosiologi diharapkan dapat menyumbangkan pemikirannya untuk ikut memecahkan masalah pendidikan yang fundamental.
Dalam (Abu Ahmadi : 2007) Sosiologi pendidikan tidak hanya mempelajari masalah-masalah sosial dalam pendidikan saja melainkan juga tujuan pendidkan, bahan kurikulum, strategi belajar mengajar, sarana belajar dan sebagainya .

Sosiologi pendidikan adalah ilmu yang berusaha mengetahui cara-cara mengendalikan proses pendidikan untuk memperoleh perkembangan kepribadian individu yang lebih baik (S. Nasution : 2011)

Guru juga harus berkelakuan menurut harapan masyarakatnya. Dari guru, sebagai pendidik dan pembangun generasi baru diharapkan tingkah laku yang bermoral tinggi demi masa depan bangsa dan Negara. Kepribadian guru dapat mempengaruhi suasana kelas / sekolah baik kebebasan yang dinikmati anak dalam mengeluarkan buah pikiran, dan mengembangkan kreatifitasnya ataupun pengekangan dan keterbatasan yang dialami dalam pengembangan pribadinya. Ini merupakan hal yang harus dipahami dan diperhatikan oleh guru.

Kita ketahui bahwa siswa dalam perkembangannya dipengaruhi oleh orang tua / wali (pendidikan informal), guru - guru (pendidikan formal), dan masyarakat (pendidikan non formal). Keberhasilan pendidikan disekolah bukan hanya ditentukan oleh usaha murid secara individual atau berkat interaksi murid dan guru dalam proses belajar mengajar,

\section{p-ISSN 2407-4934 \\ e-ISSN 2355-1747}


melainkan juga oleh interaksi siswa dengan lingkungan sosialnya dalam berbagai situasi yang dihadapi di dalam maupun di luar sekolah. Siswa berbeda - beda dalam bakat atau pembawaannya, terutama karena pengaruh lingkungan sosial yang berlainan. Pendidikan itu sendiri dapat dipandang sebagai sosialisasi yang terjadi dalam interaksi sosial.

Dalam (Abu Ahmadi : 2007) guru berusaha memahami peranan sosiologi dari kegiatan sekolah terhadap masyarakat terutama apabila sekolah ditinjau dari segi kegiatan intelektual ,untuk mengetahui seberapa jauh guru dapat membina kegiatan sosial anak didiknya untuk mengembangkan kepribadian anak. Maka sudah sewajarnya bila seorang guru berusaha menganalisis pendidikan dari segi sosiologi, mengenai hubungan manusia dalam keluarga, sekolah dan masyarakat. Ini adalah hal yang mutlak yang harus dilaksanakan guru

\section{B. Peran Guru Dalam Proses Belajar Mengajar}

Guru sangat berperan didalam proses belajar mengajar yaitu menyampaikan ilmun yang dimiliki kepada siswanya.Guru merupakan sumber belajar siswanya. Dari guru lah siswa mendapatkan pengetahuan dan pendidikan karakter. Guru sebagai orang tua kedua yang ada disekolah setelah orang tua kandung dirumah . Perkembangan baru terhadap pandangan belajar mengajar membawa konsekuensi kepada guru untuk meningkatkan peranan dan kompetensinya karena proses belajar mengajar dan hasil belajar siswa sebagian besar ditentukan oleh peranan dan kompetensi guru. Guru yang kompeten akan lebih mampu mengelola kelasnya sehingga hasil belajar siswa berada pada tingkat optimal.

Berikut peranan guru yang dianggap paling dominan yaitu :

\section{Guru sebagai demonstator}

Sebagai demonstrator atau pengajar, guru hendaknya senantiasa menguasai bahan atau materi pelajaran yang akan diajarkannya serta senantiasa mengembangkannya dalam arti meningkatkan kemampuannya dalam ilmu yang dimiliki karena hal ini akan sangat menentukan hasil belajar yang dicapai siswa. Salah satu yang harus diperhatikan oleh guru bahwa ia sendiri adalah belajar. Ini berarti bahwa guru harus terus menerus belajar. Dengan cara demikian ia akan memperkaya dirinya dengan berbagai ilmu pengetahuan sebagai bekal dalam melaksanakan tugasnya sebagai pengajar dan demonstator sehingga mampu memeragakan apa yang diajarkannya secara didaktis. Maksudnya agar apa yang disampaikannya itu betul - betul dimiliki oleh siswa. Juga hendaknya seorang guru mampu dan terampil dalam merumuskan dan memahami kurikulum, dan dia sendiri sebagai

p-ISSN 2407-4934 e-ISSN 2355-1747 
sumber belajar terampil dalam merumuskan dan memahami kurikulum, dan dia sendiri sebagai sumber belajar terampil dalam memberikan informasi kepada kelas. Sebagai pengajar, iapun harus membantu perkembangan siswa untuk dapat menerima, memahami, serta menguasai ilmu pengetahuan. Untuk itu guru hendaknya mampu memotivasi siswa untuk senantiasa belajar dalam berbagi kesempatan.

\section{Guru sebagai pengelola kelas}

Sebagai pengelola kelas, Dalam perannya sebagai pengelola kelas, guru hendaknya mampu mengelola kelas sebagai lingkungan belajar serta merupakan aspek dari lingkungan sekolah yang perlu diorganisasi. Lingkungan ini diatur dan diawasi agar kegiatan-kegiatan belajar terarah kepada tujuan pendidikan. Lingkungan yang baik adalah yang bersifat menantang dan merangsang siswa untuk belajar, memberikan rasa aman dan kepuasan dalam mencapai tujuan Sebagai manajer guru bertanggungjawab memelihara lingkungan fisik kelasnya agar senantiasa menyenangkan untuk belajar dan mengarahkan atau membimbing proses intelektual dan social dalam kelasnya. Salah satu manajemen kelas yang baik adalah menyediakan kesempatan bagi siswa untuk demi sedikit mengurangi ketergantungannya pada guru sehingga mereka mampu membimbing kegiatannya sendiri. Sebagai manajer lingkungan guru hendaknya mampu mempergunakan pengetahuan tentang teori-teori belajar mengajar dan teori perkembangan sehingga kemungkinan untuk menciptakan situasi belajar mengajar yang menimbulkan kegiatan belajar pada siswa akan mudah dilaksanakan dan sekaligus memudahkan pencapaian tujuan yang diharapkan.

\section{Guru Sebagai Mediator Dan Fasilitator}

Sebagai mediator guru hendaknya memiliki pengetahuan dan pemahaman yang cukup tentang media pendidikan karena media pendidikan merupakan alat komunikasi untuk lebih mengefektifkan proses belajar mengajar. Dengan demikian media pendidikan merupakan dasar yang diperlukan yang bersifat melengkapi dan merupakan bagian integral demi berhasilnya proses pendidikan dan pengajaran disekolah. Guru tidak hanya cukup memiliki pengetahuan tentang media pendidikan, tetapi juga harus memiliki ketrampilan memilih dan media yang sesuai dengan tujuan, materi, metode, evaluasi, dan kemampuan guru serta media yang sesuai dengan tujuan, materi, metode, evaluasi, dan kemampuan guru serta minat dan kemampuan siswa. Sebagai

\section{p-ISSN 2407-4934 \\ e-ISSN 2355-1747}


fasiltator, guru hendaknya mampu mengusahakan sumber belajar yang berguna serta dapat menunjang pencapaian tujuan dan proses belajar mengajar, baik yang berupa nara sumber, buku teks, majalah ataupun surat kabar.

\section{Guru sebagai evaluator}

Sebagai evaluator, Guru hendaknya menjadi seorang evaluator yang baik, kegiatan ini dimaksudkan untuk mengetahui apakah tujuan yang telah dirumuskan itu tercapai atau belum, dan apakah materi yang diajarkan sudah cukup tepat. Semua pernyataan tersebut akan dapat dijawab melalui kegiatan evaluasi atau penilaian. Dengan penilaian guru dapat mengklasifikasikan apakah seorang siswa termasuk kelompok siswa yang pandai, sedang, kurang atau cukup baik dikelasnya jika dibandingkan dengan temantemannya. Guru juga dapat mengetahui apakah proses belajar yang dilakukan cukup efektif memberikan hasil yang baik dan memuaskan atau sebaliknya. Jadi jelaslah bahwa guru hendaknya mampu dan terampil dalam melaksanakan penilaian karena dengan evaluasi guru dapat mengetahui prestasi siswa setelah melaksanakan proses belajar mengajar. Guru hendaknya terus menerus mengikuti hasil belajar yang telah dicapai siswa dari waktu ke waktu. Informasi yang diperoleh merupakan feedback terhadap proses belajar mengajar. Umpan balik ini akan dijadikan titik tolak untuk memperbaiki dan meningkatkan belajar mengajar selanjutnya.

\section{Korektor}

Sebagai korektor, guru harus bias membedakan mana nilai yang baik dan mana nilai yang buruk. Kedua nilai yang berbeda ini harus betul-betul dipahami dalam kehidupan di masyarakat.

\section{Inspirator}

Sebagai inspirator, guru harus memberikan inspirasi bagi kemajuan belajar siswa. Persoalan belajar adalah masalah utama anak didik, guru harus dapat memberikan petunjuk bagaimana cara belajar yang baik.

\section{Organisator}

Sebagai organisator adalah sisi lain dari peranan yang diperlukan guru, dalam bidang ini guru memiliki kegiatan pengelolaan. Kegiatan akademik dan sebagainya. Semua diorganisasikan sehingga seperti mencapai efektifitas dan efisiensi dalam belajar pada siswa.

\section{Motivator}

Sebagai motivator, guru hendaknya dapat mendorong anak didik agar bergairah dan aktif belajar. Hal ini harus benar benar dapat dilaksanakan oleh setiap guru sehingga siswa bisa termotivasi dan 
aktif disekolah seiring dengan pesatnya kemajuan teknologi saat in

\section{Inisiator}

Sebagai inisiator guru harus dapat menjadi pencetus ide-ide kemajuan dalam pendidikan dan pengajaran. Ide ide cemerlang dan membangun sangat diharapkan untuk memotivasi siswa sehingga menjadi kan siswa yang mempunyai inisiatif

\section{Pembimbing}

Sebagai pembimbing guru hendaknya membimbing siswa menjadi manusia dewasa susila yang cakap.baik disekolah maupun dilingkungan tempat tinggalnya

\section{Supervisor}

Sebagai supervisor, guru hendaknya dapat membantu, memperbaiki dan menilai secara kritis terhadap proses pengajaran. Teknikteknik supervise guru kuasai dengan baik agar dapat melakukan perbaikan terhadap situasi belajar mengajar menjadi lebih baik.

\section{Peran Guru Secara Pribadi}

Dilihat dari dirinya sendiri, seorang guru harus berperan sebagai berikut:

1. Petugas sosial, yaitu seorang yang harus membantu untuk kepentingan masyarakat. Dalam kegiatan-kegiatan masyarakat guru senantiasa merupakan petugas-petugas yang dapat dipercaya untuk berpartisipasi didalamnya.

2. Pelajar dan ilmuan, yaitu senantiasa terus menerus menuntut ilmu pengetahuan. Dengan berbagai cara setiap saat guru senantiasa belajar untuk mengikuti perkembangan ilmu pengetahuan.

3. Orang tua, yaitu mewakili orang tua murid di sekolah dalam pendidikan anaknya. Sekolah merupakan lembaga pendidikan setelah keluarga, sehingga dalam arti luas sekolah merupakan keluarga, guru berperan sebagai orang tua bagi siswanya.

4. Pencarian teladan, yaitu yang senantiasa mencarikan teladan yang baik untuk siswa. Guru menjadi ukuran bagi normanorma tingkah laku.

5. Pemberi keamanan, yaitu yang senantiasa mencarikan rasa aman bagi siswa. Guru menjadi tempat berlindung bagi siswa memperoleh rasa aman dan puas di dalamnya.

\section{SIMPULAN}

Dalam dunia pendidikan peran guru sangat penting. Oleh karena itu guru sebagai seorang tenaga pendidik haruslah memahami dan melaksanakan sosiologi pendidikan 
karena guru mempunyai beberapa peran, baik perannya secara pribadi maupun perannya dalam proses belajar mengajar. Pendidikan adalah wahana untuk membangun sumber daya manusia yang bermutu.Peran sosiologi pendidikan sangat penting dalam dunia pendidikan terutama dalam menangani kasus - kasus pendidikan dengan masalah masalah sosial. Oleh karenanya peran guru sangat penting. Guru merupakan sumber belajar siswanya. Dari guru lah siswa mendapatkan pengetahuan dan pendidikan karakter. Guru sebagai orang tua kedua yang ada disekolah setelah orang tua kandung dirumah

Untuk itu diharapkan para guru harus paham dan dibekali dengan sosiologi pendidikan serta terampil mengoperasionalkannya dalam kegiatan pendidikan.

Dengan memahami sosiologi pendidikan diharapkan para guru akan dapat mengetahui cara - cara mengendalikan proses pendidikan untuk dapat mengembangkan kepribadian individu ( siswa ) kearah yang lebih baik.

\section{DAFTAR RUJUKAN}

Ahmadi, Abu. 2007. Sosiologi Pendidikan. Jakarta: Rineka Cipta

Gunawan, Ary H. 2000. Sosiologi Pendidikan: suatu analisis sosiologi tentang pelbagai problem pendidikan. Jakarta: Rineka Cipta.

Nasution, S. 2011. Sosiologi Pendidikan. Jakarta: Bumi Aksara

Ratna,Dahar Willis, 1991. TeoriTeori Belajar. Jakarta: Gelora Aksara Pratama

UU No 14 tahun 2005 tentang guru dan dosen https://fisipsosiologi.wordpress .com 